\title{
A nanoparticle bed micro-reactor with high syngas yield for moderate temperature micro-scale SOFC power plants
}

\author{
Alejandro J. Santis-Alvarez ${ }^{\mathrm{a}}$, Majid Nabavi ${ }^{\mathrm{a}}$, Bo Jiang ${ }^{\mathrm{bc}}$, Thomas Maeder ${ }^{\mathrm{b}}$, Paul Muralt ${ }^{\mathrm{c}}$, \\ Dimos Poulikakos ${ }^{\text {a,1 }}$ \\ ${ }^{\text {a }}$ Laboratory of Thermodynamics in Emerging Technologies, Institute of Energy Technology, Department of \\ Mechanical and Process Engineering, ETH Zurich, CH-8092 Zurich, Switzerland \\ ${ }^{\mathrm{b}}$ Laboratory of Micro-engineering for Manufacturing, EPFL Lausanne, CH-1015 Lausanne, Switzerland \\ ${ }^{\mathrm{c}}$ Laboratory of Ceramics, EPFL Lausanne, _CH-1015 Lausanne, Switzerland
}

\begin{abstract}
This work introduces and investigates the a novel compact catalytic nanoparticle bed microfabricated reactor suitable for utilization in small-scale intermediate-temperature micro-SOFC systems. It is shown that the presented micro-reactor is able to produce syngas $\left(\mathrm{CO}+\mathrm{H}_{2}\right)$ efficiently from n-butane and propane at temperatures between $550-620{ }^{\circ} \mathrm{C}$ by means of catalytic partial oxidation (CPOX) using Rh-doped nanoparticles embedded in a foam-like porous ceramic bed as a catalyst. The novel micro-fabricated reactor system is experimentally tested using a carrier specially designed for heating the reactor as well as feeding the fuel and receiving the reaction product gases. Optimization of the syngas production is performed by varying fuel dilutions and reactor temperatures. The performance of the micro-reactor was investigated in two modes: (1) Continuous heating mode, in which two built-in heaters underneath the carrier are kept on throughout the reforming reaction. This simulates the operating state of a micro-SOFC system where the post-combustor provides heat to the microreformer continuously. (2) Thermally self-sustained mode, in which the heaters are turned off after the CPOX has been ignited. An estimation of the heat losses of both testing modes is also given. The present micro-reactor is able to achieve syngas yield as high as $60 \%$ for $n$ butane and $50 \%$ for propane in the continuous heating mode, which is a substantial improvement to state-of-the-art micro-reactors.
\end{abstract}

Keywords: Chemical micro-reactors; Catalytic partial oxidation; Packed bed; Reaction engineering; Nanoparticles; Micro-SOFC power plant

1 Corresponding author: Tel.: + 414463227 38; fax: + 41446321176. E-mail address: dimos.poulikakos@ethz.ch 


\section{Highlights}

- A novel compact catalytic nanoparticle bed micro-fabricated reactor is introduced

- A specially designed carrier for testing the micro-reactor is fabricated.

- The micro-reactor can be integrated in small-scale SOFC systems.

- The micro-reactor is able to achieve higher syngas yield for n-butane and propane than state of the art micro-reactors.

\section{Broader context}

Miniaturized solid oxide fuel cell (e.g micro-SOFC) power plants are believed to constitute one of the technologies that could help satisfy the continuously increasing electric energy demand for small mobile devices. One of the main challenges in such systems is to produce syngas $\left(\mathrm{CO}+\mathrm{H}_{2}\right)$ efficiently on board from hydrocarbons at intermediate temperatures around $550{ }^{\circ} \mathrm{C}$. In this work, we present a compact catalytic nanoparticle bed micro-fabricated reactor concept capable of producing sufficient syngas to power a micro-SOFC power plant. The micro-reactor can be directly integrated with the micro-SOFC membrane and the postcombustor and is estimated to deliver enough syngas for the production of electrical energy in the range of $1-2 \mathrm{~W}$.

\section{Notation}

$\dot{V}_{\text {in }}$

$\mathrm{C} / \mathrm{O}$

$\dot{Q}_{\text {loss,reaction }}$

$\dot{Q}_{\text {loss,total }}$

$S_{\mathrm{i}}$

$T$

$T_{\text {carrier }}$

$T_{\text {op }}$

$T_{\text {set }}$

$t_{\text {space }}$

$V_{\text {reactor }}$

\section{Greek letters}

\section{$\eta$}

$\psi_{\mathrm{i}} \quad$ Yield of species $i$

$\phi \quad \mathrm{C} / \mathrm{O}$ ratio

$\sigma \quad$ Standard deviation

Temperature $/{ }^{\circ} \mathrm{C}$

Space time / $\mathrm{ms}$

Fuel conversion
Volumetric flow rate at reactor inlet $/ \mathrm{cm}^{3} \mathrm{~min}^{-1}$

Fuel to oxygen ratio

Heat losses of reaction $/ \mathrm{J} \cdot \mathrm{s}^{-1} \cdot \mathrm{mol}^{-1} \mathrm{C} 4 \mathrm{H} 10, \mathrm{~J} \cdot \mathrm{s}^{-1} \cdot \mathrm{g}^{-1}$ feed gas

Total heat losses of the system $/ \mathrm{J} \cdot \mathrm{s}^{-1}$

Selectivity of species $i$

Temperature at the carrier on top of heater $\mathrm{B} /{ }^{\circ} \mathrm{C}$

Operating temperature at steady state $/{ }^{\circ} \mathrm{C}$

Temperature on top of micro-reactor without gas flow $/{ }^{\circ} \mathrm{C}$

Reactor volume $/ \mathrm{cm}^{3}$ 


\section{Introduction}

Micro-scale fuel cell devices are being investigated intensively, due to their potential to deliver higher energy density than common Li-ion-batteries [1-4] combined with the inherent fuel cell features in power generation. Among all fuel cell types, solid oxide fuel cells (SOFC) have the advantage of coupling high fuel flexibility with high efficiency and long-term stability. Due to the high operating temperature of SOFCs, a wide variety of hydrocarbons can be reformed to generate syngas fuel $\left(\mathrm{CO}+\mathrm{H}_{2}\right)$ either directly on the anode (internal reforming) [5-10] or in a separate reactor (external reforming) [11]. The decoupling of syngas generation from the SOFC-membranes has the advantage of allowing an easier and more precise optimization of the fuel-processing unit, leading to an increase in the overall efficiency of such a system.

Studies on micro-scale fuel processors for small-scale fuel cell devices have been primarily focused on steam reforming of hydrocarbons and alcohols [12-17] mostly at temperatures below $350{ }^{\circ} \mathrm{C}$. Tanaka et al. [18] introduced a micro-fuel reformer system able to reform methanol at temperatures as low as $180^{\circ} \mathrm{C}$. The heat in the system was provided by either a micro-heater or by an integrated micro-combustor, in which n-butane was oxidized in order to produce enough heat for the endothermic reforming reaction.

Micro-fabricating reactors with a needed broad palette of materials becomes challenging as the operating temperature requirements increase. High temperature micro-structured reactors have been investigated primarily for hydrocarbon-to-hydrogen-conversion [19-22]. Pennemann et al. [20] studied a micro-structured reactor for the partial oxidation of propane at temperatures between 700 and $850^{\circ} \mathrm{C}$. For this purpose, novel metals like palladium, platinum and rhodium on alumina were wash-coated onto the micro-structured channels of their reactors. The high temperatures were obtained from an external heating source. Metzler et al. [19] introduced a micro-fabricated silicon-reactor setup for the partial oxidation of methane at high-temperatures. In their study, the reaction is catalyzed on a palladium-coated channel and activated using an external resistive heating device placed on top of the reactor chip. The fabrication procedures of such metal coated micro-reactors are complicated and time consuming. There is a need for cost-effective, simple fabrication techniques for such devices.

The novelty of the present work is the introduction of a feasible, compact, micro-fabricated reactor/catalyst concept and the study of its suitability to produce syngas efficiently at intermediate temperatures (between $550-620^{\circ} \mathrm{C}$ ) for micro-SOFC applications. The syngas is generated from n-butane and propane:

$$
\begin{aligned}
& \mathrm{n}-\mathrm{C}_{4} \mathrm{H}_{10}+2 \mathrm{O}_{2} \stackrel{\text { Cat. }}{\longrightarrow} 4 \mathrm{CO}+5 \mathrm{H}_{2} \\
& \mathrm{C}_{3} \mathrm{H}_{8}+\frac{3}{2} \mathrm{O}_{2} \stackrel{\text { Cat. }}{\longrightarrow} 3 \mathrm{CO}+4 \mathrm{H}_{2}
\end{aligned}
$$

These hydrocarbons are selected because of their high energy content $(45.7 \mathrm{MJ} / \mathrm{kg}$ and 26.2 $\mathrm{MJ} / \mathrm{L}$ at $25{ }^{\circ} \mathrm{C}$ for $\mathrm{n}$-butane and $46.4 \mathrm{MJ} / \mathrm{kg}$ and $22.8 \mathrm{MJ} / \mathrm{L}$ at $25{ }^{\circ} \mathrm{C}$ for propane, respectively), feasible portability due to relatively low vapor pressure (243 $\mathrm{kPa}$ and $952 \mathrm{kPa}$ at 
$25{ }^{\circ} \mathrm{C}$ for n-butane and propane, respectively), their high availability and their wide societal acceptance.

Rhodium metal on ceria-zirconia support $\left(\mathrm{Ce}_{0.5} \mathrm{Zr}_{0.5} \mathrm{O}_{2}\right)$ nanoparticles is used as catalytic material due to its proven ability to deliver high syngas yield at different intermediate temperatures and fuel dilutions [23-25]. The Rh-catalyst is embedded in the micro-reactor by a one-step sol-gelation process described in [26], which allows filling of nanoparticles in different reactor shapes, thus avoiding expensive and cumbersome deposition procedures or other complex coating or impregnation steps. This simple process has proven to be reliable for small size reactors, as the one reported in this study.

For reactor heating, two built-in screen-printed resistive heaters on a specially fabricated micro-reactor carrier unit were employed. This carrier unity was fabricated by a thin film deposition process utilizing standard thin-film procedures and also served as support for gas transport to and from the micro-reactor.

The micro-reformer presented here can be integrated directly in a micro-SOFC power plant and is shown to be capable of producing enough syngas and serve as a gas processing unit for such a device.

\section{Experimental methods}

\subsection{The micro-reactor and the carrier testing platform}

The micro-reactor used in this study was fabricated by standard micro-fabrication techniques on a $1000 \mu \mathrm{m}$ thick Si-substrate (Fig. 1a). The substrate was etched to a depth of $500 \mu \mathrm{m}$ using potassium hydroxide $(\mathrm{KOH})$. Masks with compensation structures for the pins and the walls were used in order to obtain the desired $1.5 \mathrm{~mm} \times 1.5 \mathrm{~mm}$ quadratic pins (needed for structural integrity) and the $5 \mathrm{~mm} \times 0.5 \mathrm{~mm}$ rectangular structures (at the walls, for mechanical stability at the borders) during $\mathrm{KOH}$-etching. A $1000 \mu \mathrm{m}$ thick borosilicate glass 3.3 with two drilled holes of $2 \mathrm{~mm}$ in diameter was subsequently anodically bonded onto the $\mathrm{Si}$-substrate. The dimensions of the catalytic bed and the micro-reactor are $11.0 \mathrm{~mm} \times 11.5$ $\mathrm{mm} \times 0.5 \mathrm{~mm}$ and $12.7 \mathrm{~mm} \times 12.7 \mathrm{~mm} \times 2.0 \mathrm{~mm}$, respectively. The catalytic bed volume $\left(V_{\text {reactor}}\right)$ is $58.5 \mathrm{~mm}^{3}$.

The optimization of the reactor design was accomplished by standard numerical simulations (not presented for brevity) of gas flow in a porous layer simulating the catalyst bed, performed using the CFX package (version 12.1) for ten different reactor geometries. The numerical study showed that the present design with two square pins in the micro-reactor enhanced flow uniformity and distribution and minimized dead volumes.

The $1.9 \mathrm{wt} \% \mathrm{Rh}$ on $\mathrm{Ce}_{0.5} \mathrm{Zr}_{0.5} \mathrm{O}_{2}$ catalytic nanoparticles with an average diameter of $12 \mathrm{~nm}$ were synthesized in a one-step process by flame spray synthesis as described in [23]. The catalytic ceramic foam was prepared by a one-step sol gelation process as described and characterized in [26]. As in previous studies [23,24,26,27], we kept the same nanoparticle to sand weight ratio to $1: 3$. For preparation of the ceramic foam, $24.1 \mathrm{wt} \%$ catalytic nanoparticles, 72.2 wt \% washed and calcined $\mathrm{SiO}_{2}$-sand (Riedel-deHaën, average diameter: $200 \mu \mathrm{m}$, puriss p.a.), $0.9 \mathrm{wt} \%$ gelation agent (triammonium citrate, Riedel-deHaën, purity $\geq$ 
97\%) and $2.8 \mathrm{wt} \%$ ceramic binder (sodium metasilicate pentahydrate, Riedel-deHaën, purity $\geq 97 \%$ ) were mixed with the same mass of deionized water $(18 \mathrm{M} \Omega)$. The mixture was manually stirred and then placed in an ultrasonic bath for $5 \mathrm{~min}$. These steps resulted in a highly viscous suspension which was then introduced inside the micro-reactor through the openings. The reactor was shaken regularly during the filling process in order to avoid empty areas that could result in unused or dead volumes. The water in the reactor was removed by thermal treatment after heating up to $100{ }^{\circ} \mathrm{C}$ with a heating rate of $2.5^{\circ} \mathrm{C} / \mathrm{min}$ and by keeping this temperature for $60 \mathrm{~min}$. The reactor was heated up to $650{ }^{\circ} \mathrm{C}$ for $20 \mathrm{~min}$ with a heating rate of $10{ }^{\circ} \mathrm{C} / \mathrm{min}$. This step was necessary in order to ensure that the catalytic bed could sustain such high temperature levels without any crack formation (Fig. 1a).

In order to be able to characterize the micro-reactor, a specially-designed carrier unit was fabricated using standard thin film fabrication techniques (Fig. 1b and c). The carrier has two important functionalities: First, it allows the gas transport to and from the micro-reactor at the intermediate temperatures needed for this study and second, it provides the necessary activation temperature of the reaction by means of two resistive heaters.

The carrier was made of two layers of Schott AF $32 \AA$ Eco Glass which tolerates high operating temperatures (thermal expansion coefficient $=3.2 \times 10^{-6} \mathrm{~K}^{-1}$, transformation temperature $=717{ }^{\circ} \mathrm{C}$, Schott AG). As material for the carrier, we chose glass instead of silicon to prevent heat transfer from the reaction zone through the carrier to the inlet and outlet connections. Glass also provides much better thermal insulation for the micro-reactor, which is desirable when high operating temperatures are needed. The micro-channels were fabricated between two glass layers (Fig. $1 \mathrm{~b}$ and c). For this purpose, a glass frit powder (Ferro IP 760c, Ferro Corporation) was formulated with a vehicle consisting of ethyl cellulose binder (EC-300-48, Sigma Aldrich), plasticized with triethylene glycol bis(2-ethylhexanoate) and dissolved in a terpineol - dibutyl carbitol solvent mix. The paste was screen-printed onto both glass plates. The assembly was accomplished by heating up to $700{ }^{\circ} \mathrm{C}$ under a load of $150 \mathrm{~g}$ to ensure tightness of glass frit walls between the micro-channels. The average thickness of the glass frit layer (height of micro-channels) was $150 \mu \mathrm{m}$. The dimensions of the carrier were $75 \mathrm{~mm} \times 12 \mathrm{~mm} \times 1.75 \mathrm{~mm}$.

The micro-reactor was also assembled on top of the carrier using the same technique. Two heating tracks made of silver and platinum were also screen printed onto the carrier glass with a thickness of $2.5 \pm 0.4 \mu \mathrm{m}$ and two widht of $0.4 \mathrm{~mm}$ and $0.6 \mathrm{~mm}$, respectively. A ceramic interconnect allowed the power supply to the heating tracks. In a final step, the mechanical interconnects were made by simply attaching two stainless steel connections using epoxy (STYCAST $2741 \mathrm{~W} 1$ - Catalyst 15, Emerson \& Cuming) on top of the carrier inlet and outlet holes (Fig. 1b). 


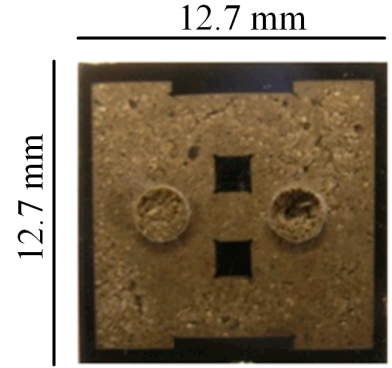

(b)
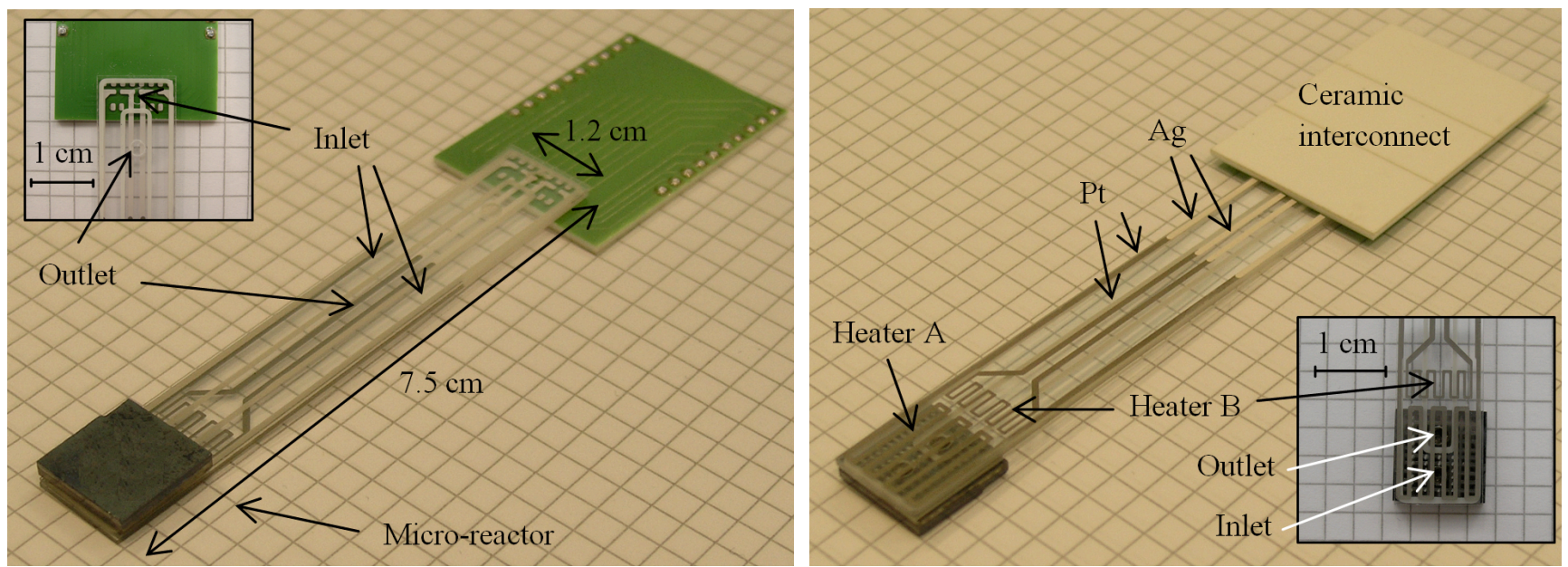

Fig. 1. (a): The micro-fabricated reactor filled with dried catalytic material. Top (b) and bottom (c) views of the assembled micro-reactor and carrier unit. The symmetric fluidic channels and built-in heaters on the carrier testing-platform are also shown.

\subsection{Test setup and procedures}

The specified hydrocarbon fuel (PanGas, purity of both hydrocarbons: $99.95 \%$ ) was diluted with synthetic air ( 80 vol\% $\mathrm{N}_{2}, 20$ vol\% $\mathrm{O}_{2}$, PanGas, $\left.99.9996 \%\right)$ at room temperature $\left(20^{\circ} \mathrm{C}\right)$ at specified fuel to oxygen ratios before the inlet of the testing platform. The different feed compositions are represented by

$$
\phi=\frac{\mathrm{x}}{2} \cdot \frac{\dot{n}_{\mathrm{C}_{\mathrm{x}} \mathrm{H}_{\mathrm{y}}, \mathrm{in}}}{\dot{n}_{\mathrm{O}_{2}, \mathrm{in}}}
$$

and their values are defined by the molar oxygen to fuel ratios in the proximity to stoichiometric CPOX reaction: 


$$
\mathrm{C}_{\mathrm{x}} \mathrm{H}_{\mathrm{y}}+\frac{\mathrm{x}}{2} \mathrm{O}_{2} \stackrel{\mathrm{Rh}}{\longrightarrow} \mathrm{xCO}+\frac{\mathrm{y}}{2} \mathrm{H}_{2}
$$

The micro-reactor testing platform was insulated with two insulation blocks (WDS®Ultra, $5 \mathrm{~cm} \times 10 \mathrm{~cm} \times 10 \mathrm{~cm}$ each, of thermal conductivity $=0.018 \mathrm{Wm}^{-1} \mathrm{~K}^{-1}$ at $50{ }^{\circ} \mathrm{C}$ varying to $0.031 \mathrm{Wm}^{-1} \mathrm{~K}^{-1}$ at $600{ }^{\circ} \mathrm{C}$, Porextherm Daemmstoffe $\mathrm{GmbH}$ ). The temperature on top of the micro-reactor was measured by two K-type thermocouples.

For the noble metal rhodium, reactions (1) and (2) are activated at temperatures above $300{ }^{\circ} \mathrm{C}$ $[24,28]$. For this purpose, two screen printed resistive heaters on the carrier were powered by a power supply in order to activate the reaction at different temperatures.

The exhaust gas composition was monitored by a gas chromatograph (6890 GC, with a HPMOLSIV and a HP-PlotQ column, Agilent) every $25 \mathrm{~min}$ until the micro-reactor reached steady state conditions. We defined steady conditions when fuel utilization (conversion) and syngas yield showed no significance variation with time (standard deviation, $\sigma \leq 0.8 \%$ ) and the temperature rise remained within $1{ }^{\circ} \mathrm{C}$ during 10 to $15 \mathrm{~min}$. We defined $T_{\mathrm{op}}$ as the operation temperature at which steady conditions were obtained. In the case of successful reaction ignition, these conditions were achieved after approximately 95 and $120 \mathrm{~min}$ of reaction time. After this time the reaction was terminated by stopping the gas flow. The molar product gas balances for $\mathrm{C}, \mathrm{H}$ and $\mathrm{O}$ atoms closed within $5 \%$ for all experiments.

The results of the gas analysis were quantified primarily by means of fuel conversion, hydrogen yield, syngas yield and molar methane to inlet fuel ratio (Table 1).

Fuel conversion:

$$
\eta=\frac{\dot{n}_{\mathrm{C}_{\mathrm{x}} \mathrm{H}_{\mathrm{y}}, \text { in }}-\dot{n}_{\mathrm{C}_{\mathrm{x}} \mathrm{H}_{\mathrm{y}}, \text { out }}}{\dot{n}_{\mathrm{C}_{\mathrm{x}} \mathrm{H}_{\mathrm{y}}, \text { in }}}
$$

Yield of $\mathrm{H}_{2}$ and $\mathrm{CO}$ :

$$
\psi_{\mathrm{H}_{2}}=2 \cdot \frac{\dot{n}_{\mathrm{H}_{2}}}{y \cdot \dot{n}_{\mathrm{C}_{x} \mathrm{H}_{\mathrm{y}}, \text { in }}} \text { and } \psi_{\mathrm{CO}}=\frac{\dot{n}_{\mathrm{CO}}}{x \cdot \dot{n}_{\mathrm{C}_{x} \mathrm{H}_{y}, \text { in }}}
$$

Yield of syngas:

$$
\psi_{\text {syngas }}=\frac{\dot{n}_{\mathrm{H}_{2}}+\dot{n}_{\mathrm{CO}}}{\left(\frac{y}{2}+x\right) \cdot \dot{n}_{\mathrm{C}_{\mathrm{x}} \mathrm{H}_{\mathrm{y}}, \text { in }}}
$$

Molar methane to inlet fuel ratio $\quad x_{\mathrm{CH}_{4}}=\frac{\dot{n}_{\mathrm{CH}_{4}}}{\dot{n}_{\mathrm{C}_{\mathrm{x}} \mathrm{y}, \text { in }}}$

Selectivity of $\mathrm{H}_{2}$ and $\mathrm{CO}$

$$
S_{\mathrm{H}_{2}}=\frac{\dot{n}_{\mathrm{H}_{2}}}{\dot{n}_{\mathrm{H}_{2}}+\dot{n}_{\mathrm{H}_{2} \mathrm{O}}} \text { and } S_{\mathrm{CO}}=\frac{\dot{n}_{\mathrm{CO}}}{\dot{n}_{\mathrm{CO}}+\dot{n}_{\mathrm{CO}_{2}}}
$$

Table 1. Characteristic values for gas composition analysis. 


\section{Results and Discussion}

We investigated the performance of the micro-reactor in two different testing modes: (1) The continuous heating mode, in which the heaters underneath the carrier are kept on throughout the reforming reactions. The continuous heat source simulates an additional unit in the system such as a post-combustor device [18,29], providing constant heat to the reactor during its operation,. The continuous heating mode is also advantageous as it helps achieving adjustable temperatures in the micro-reactor in order to characterize its performance in a systematic manner. (2) The thermally self-sustained mode, which simulates the case where the postcombustor is not present or is not thermally connected to the micro-reactor. It also simulates a possible startup scenario, with a limited, initial activation electrical heating. After activation of the thermally self-sustained reaction, the power supplied to the heaters for reaction start-up was turned off. The start of the reaction was indicated by a sudden temperature increase caused by the energy released from exothermic reaction.

In order to have comparable conditions for the abovementioned constant heating and selfsustained scenarios, we targeted temperatures at steady state between 550 and $620^{\circ} \mathrm{C}$. To accomplish this, we selected low gas flow rates, which resulted in space times $\left(t_{\text {space, }}\right.$ Eq. 5$)$ of the reactants in the catalytic bed in the range of several ms. The total inlet flow rate $\dot{V}_{\text {in }}$ for the experiments under constant resistive heating was 30 standard cubic centimeters per minute $(\mathrm{sccm})$ and for the experiments on the thermally self-sustained reaction was $60 \mathrm{sccm}$.

$$
t_{\text {space }}=\frac{V_{\text {reactor }}}{\dot{V}_{\text {gas,reactor }}}
$$

\subsection{Effect of fuel dilutions and set temperature on product composition}

In the first set of experiments, a continuous heat source was used during all experiments to obtain the desirable temperatures at the top of the micro-reactor. We defined $T_{\text {set }}$ as the temperature at the top of the micro-reactor when no gas was flowing through it, controlled by the power input to the heaters. In order to investigate and optimize the performance of the micro-reactor, we varied the carbon to oxygen ratios $(\phi)$ of the inlet gas mixture and $T_{\text {set. }}$. For both fuels we used the $\phi$ values of $1.0,0.8,0.7$ and 0.6 for a total inlet flow of $30 \mathrm{sccm}$. Stoichiometric conditions $(\phi=1.0)$ were tested as reference values, while the other values were chosen to determine $\phi$ at which the maximum CPOX performance in terms of syngas yield can be achieved.

Once the temperature on top of the micro-reactor reached the desired $T_{\text {set }}$, the reacting gas mixture was fed through the catalytic bed until $T_{\text {op }}$ was obtained. Figure 2 shows the characteristic temperature increase behavior from $T_{\text {set }}$ to $T_{\mathrm{op}}$ observed during these experiments. 


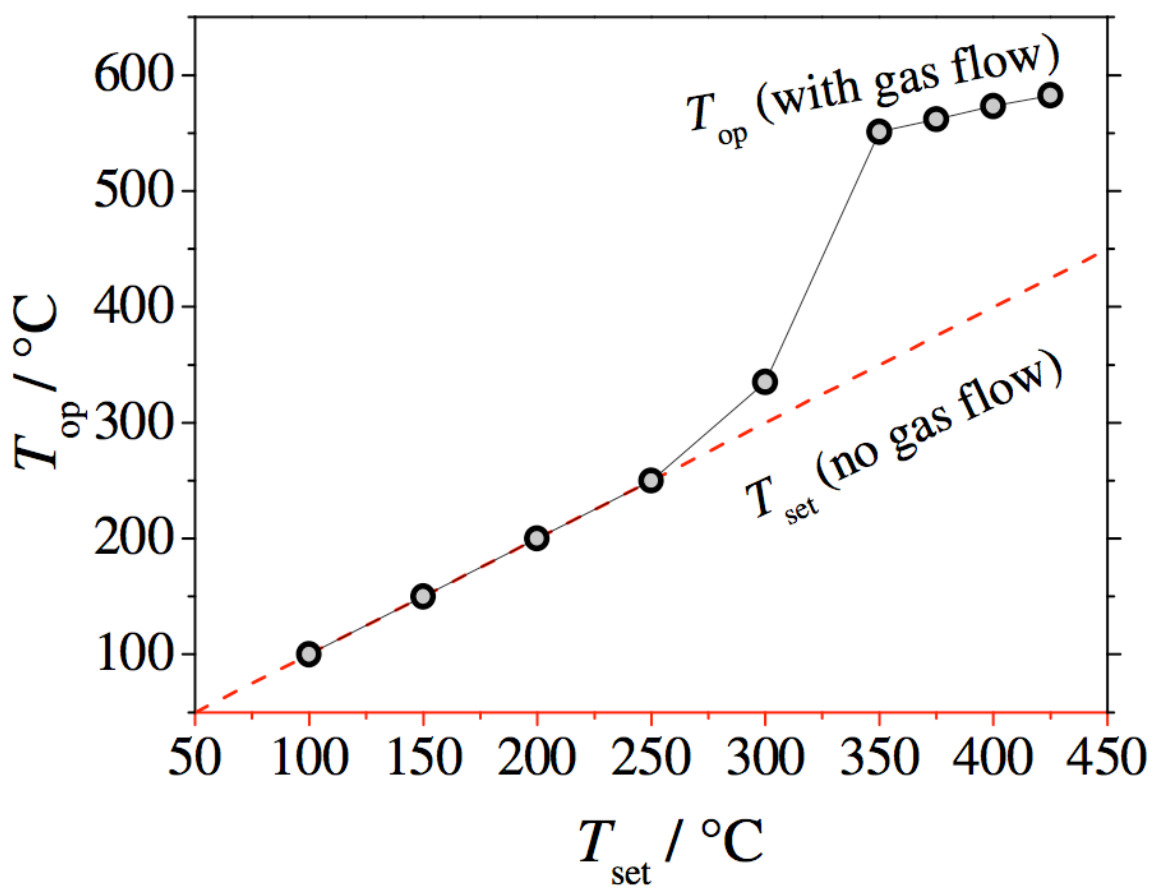

Fig. 2. Characteristic temperature behavior during testing. $T_{\text {set }}$ (dashed red line) denotes the set temperature at the micro-reactor without any gas flow and $T_{\text {op }}$ (circles) represents the microreactor temperature with a total inlet flow rate of $30 \mathrm{sccm}$ at steady state conditions.

As shown in Fig. 2, for $T_{\text {set }}<300{ }^{\circ} \mathrm{C}$, no significant change in temperature was obtained. At $T_{\text {set }}=300{ }^{\circ} \mathrm{C}$, the temperature rose only to a small extent, whereas for $T_{\text {set }} \geq 350{ }^{\circ} \mathrm{C}$, the temperature rise was significant.

Gas composition analysis showed that for $T_{\text {set }}<300{ }^{\circ} \mathrm{C}$, the diluted hydrocarbon-air mixture did not undergo any change inside the micro-reactor and that no thermal decomposition at these temperature levels occurred. At $T_{\text {set }}=300{ }^{\circ} \mathrm{C}$, fuel conversions below 15 percent were obtained and consequently the thermal decomposition products, carbon dioxide and water vapor, were identified in the outlet gas stream. For $T_{\text {set }} \geq 350{ }^{\circ} \mathrm{C}$, higher fuel conversions, hydrogen and carbon monoxide among other gases were detected, confirming the successful activation of the CPOX reaction. Also characteristic for the ignition of the CPOX reaction was the total consumption of oxygen, which could not be detected at any point in time during the gas measurements after the CPOX reactions were initiated.

The effects of $T_{\text {set }}$ and dilution ratio on $T_{\mathrm{op}}$ for n-butane and propane are depicted in Fig. 3. As in [23], the final temperature follows the same trend as the oxygen to inlet fuel ratio, increasing from 550 to almost $620{ }^{\circ} \mathrm{C}$ from higher to lower $\phi$ values i.e. when diluting towards stoichiometric total oxidation ratio ( $\phi=0.31$ for n-butane and $\phi=0.30$ for propane). At these values of $T_{\mathrm{op}}$, the calculated residence time, $t_{\mathrm{space}}$, was in the range of 40 to $44 \mathrm{~ms}$ for all reactions. As shown in Fig. 3, the increase in $T_{\text {op }}$ is lower than that in $T_{\text {set }}$, mainly due to the heat losses at these intermediate temperatures. 
(a)

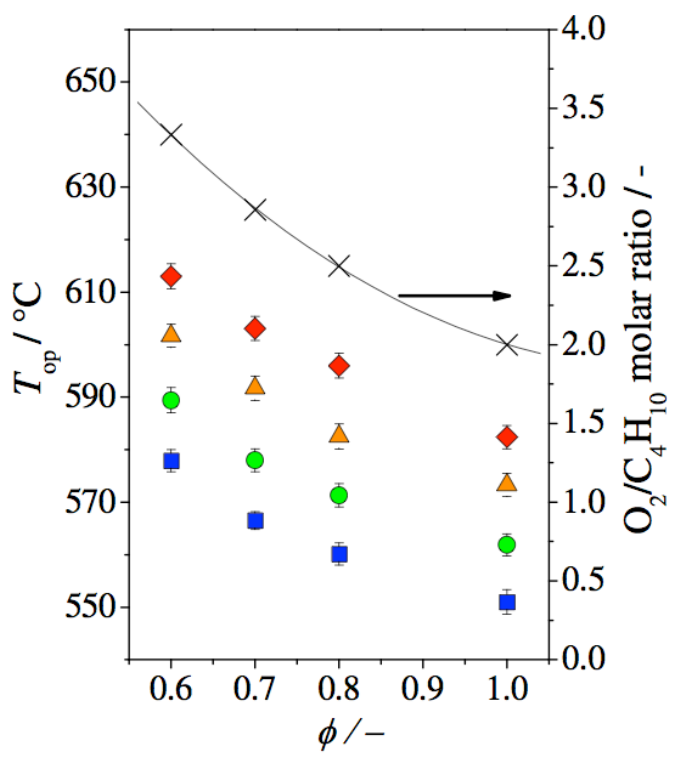

(b)

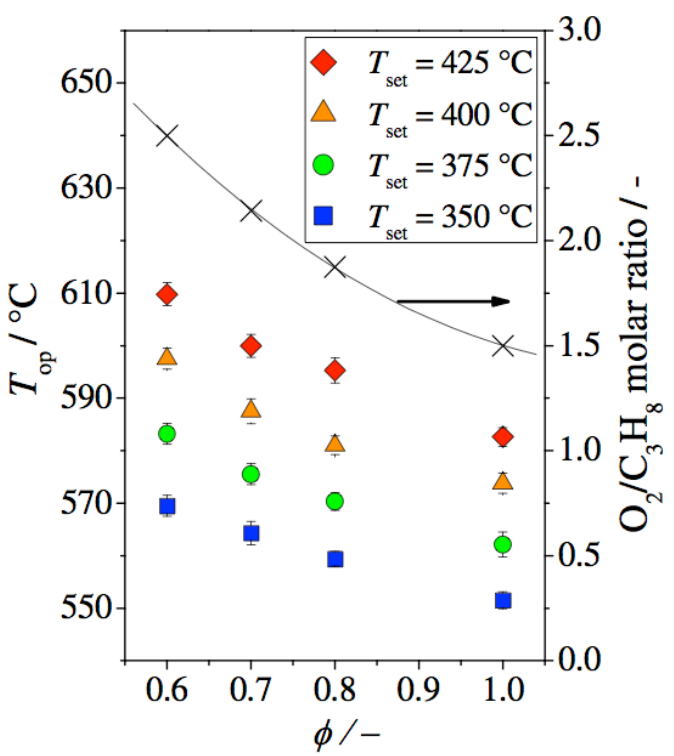

Fig. 3. Effect of $T_{\text {set }}$ and fuel dilution on $T_{\text {op }}$ for (a) n-butane and (b) propane CPOX. From $\phi=1.0$ to $0.6, T_{\text {op }}$ follows a similar trend as the $\mathrm{O}_{2} / \mathrm{C}_{\mathrm{x}} \mathrm{H}_{\mathrm{y}}$ molar ratio.

The CPOX performance of the catalytic bed varied depending on the utilized fuel, fuel dilution and heating temperature. For all reactions, the outlet gas mixture contained unconverted fuel, inert nitrogen, water vapor and carbon dioxide, as well as methane and syngas species. No traces of other gases such as $\mathrm{C}_{2}$ or $\mathrm{C}_{3}$ components were found in any case.

Figures 4 and 5 depict gas analysis results obtained for both fuels at steady conditions. As shown here, for higher $T_{\text {set, }}$, higher values of $\eta$ were obtained (Figs. 4a and 5a). For both fuels, $\eta$ becomes highly temperature dependent for lower dilutions. At $\phi=1.0$, the difference in fuel conversion ratio values is maximum between $T_{\text {set }}=350^{\circ} \mathrm{C}$ and $T_{\text {set }}=425^{\circ} \mathrm{C}$.

In contrast to fuel utilization behavior, the syngas production (Figs. $4 \mathrm{~b}$ and $5 \mathrm{~b}$ ) shows a nonmonotonic behavior for different values of $\phi$. This parameter, as well as the hydrogen yield and other parameters like methane production, has a stronger dependency on the fuel dilution ratio and has its maximum within the chosen dilution range $(\phi=0.8-0.6)$. For both fuels, maximum syngas values were found between $\phi=0.8$ and 0.7 .

The undesired methane production was highest at 0.24 moles per mole of n-butane and at 0.20 moles per mole of propane for $\phi=0.8$ and 1.0, respectively. As shown in Fig. 5d, the methane production is $T_{\text {set }}$ insensitive at the values of $\phi$ where the highest syngas production is obtained ( $\phi=0.8-0.7$, Fig. 5 b). Hence, a methanation process as methane synthesis pathway is improbable. The fact that the highest methane production per unit mole of fuel is increased at higher values of $\phi$ should be mainly caused by hydrocarbon decomposition of the higher concentrated inlet gas mixtures. 
(a)

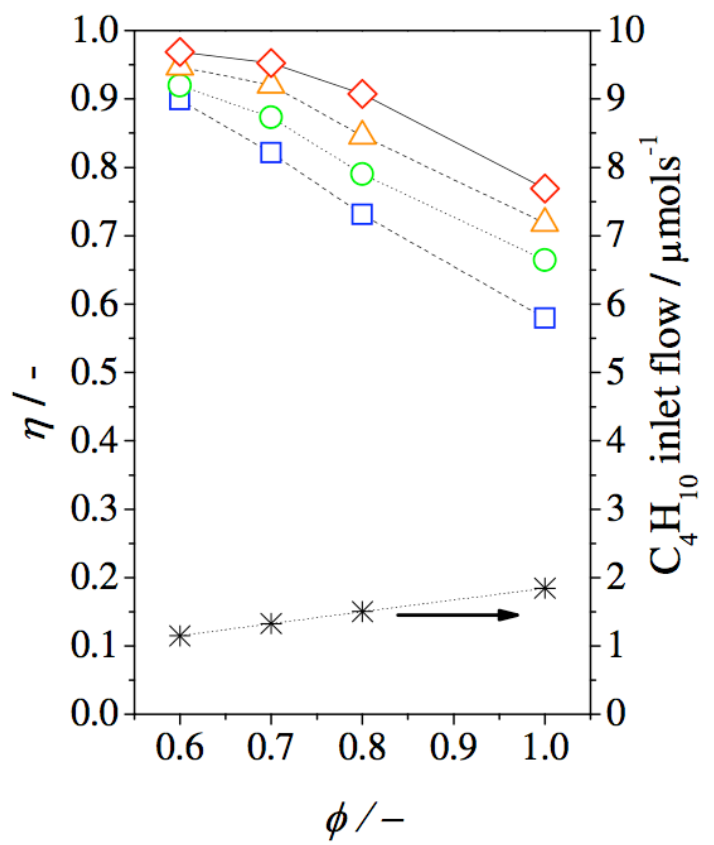

(c)

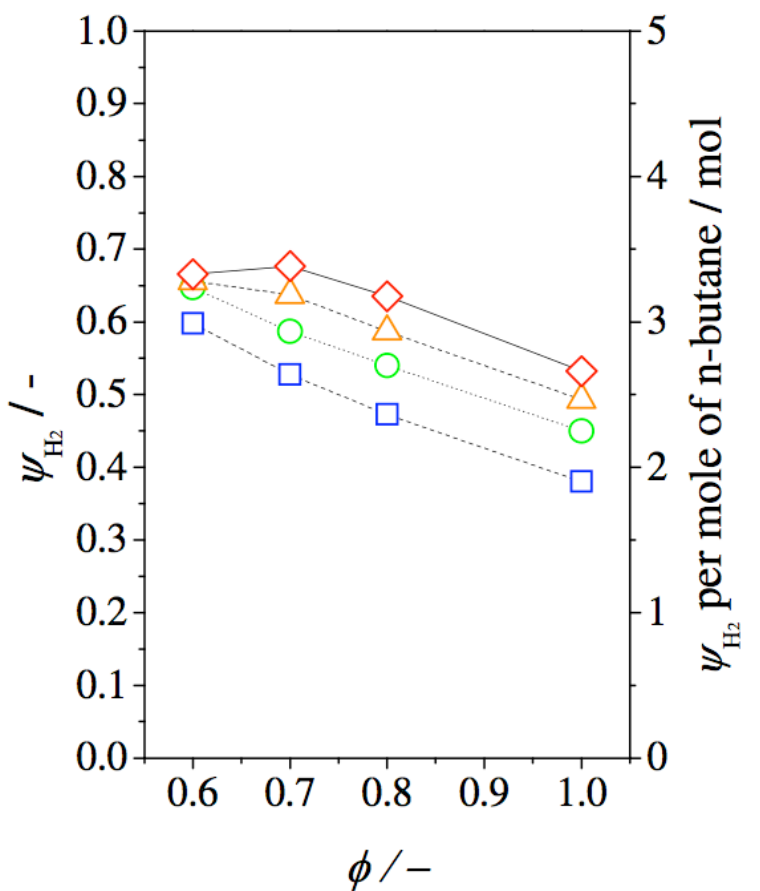

(b)

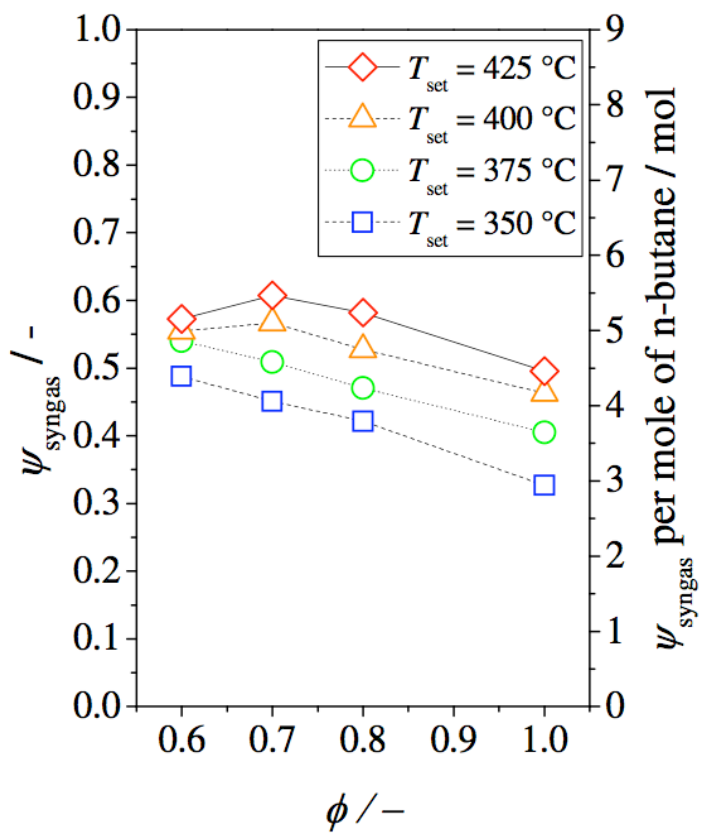

(d)

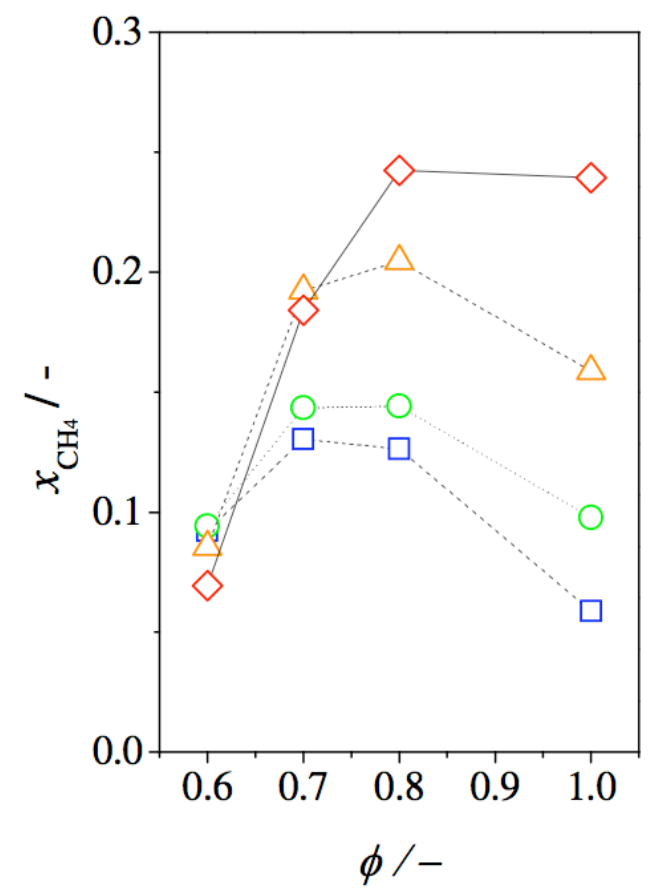

Fig. 4. Gas analysis results for n-butane for different fuel dilutions; (a) fuel conversion, (b) syngas yield, (c) hydrogen yield and (d) methane to inlet n-butane ratio. The symbols represent different Tset: squares $\left(350^{\circ} \mathrm{C}\right)$, circles $\left(375^{\circ} \mathrm{C}\right)$, triangles $\left(400^{\circ} \mathrm{C}\right)$ and diamonds $\left(425^{\circ} \mathrm{C}\right)$. 
(a)

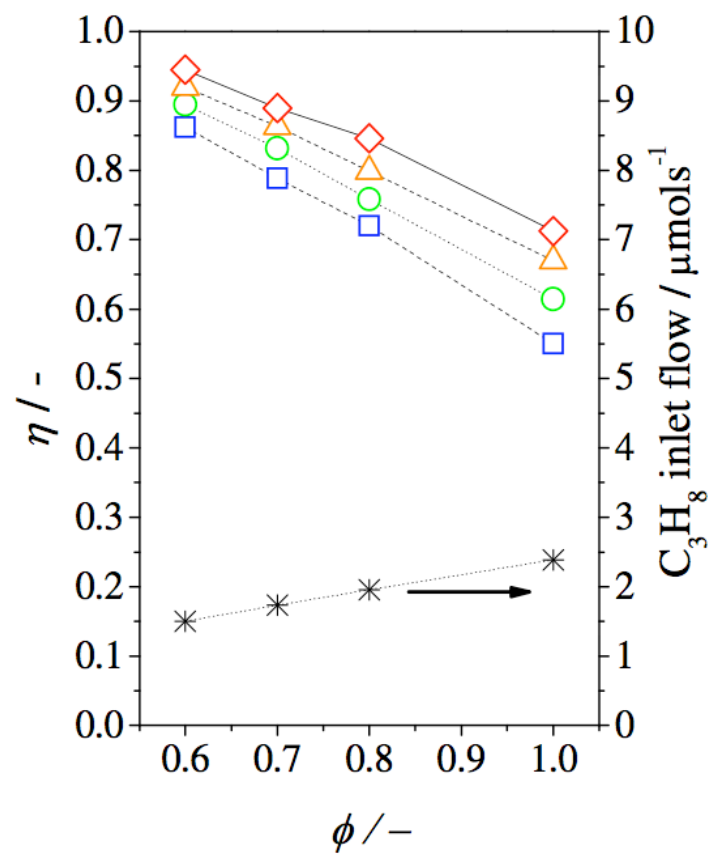

(c)

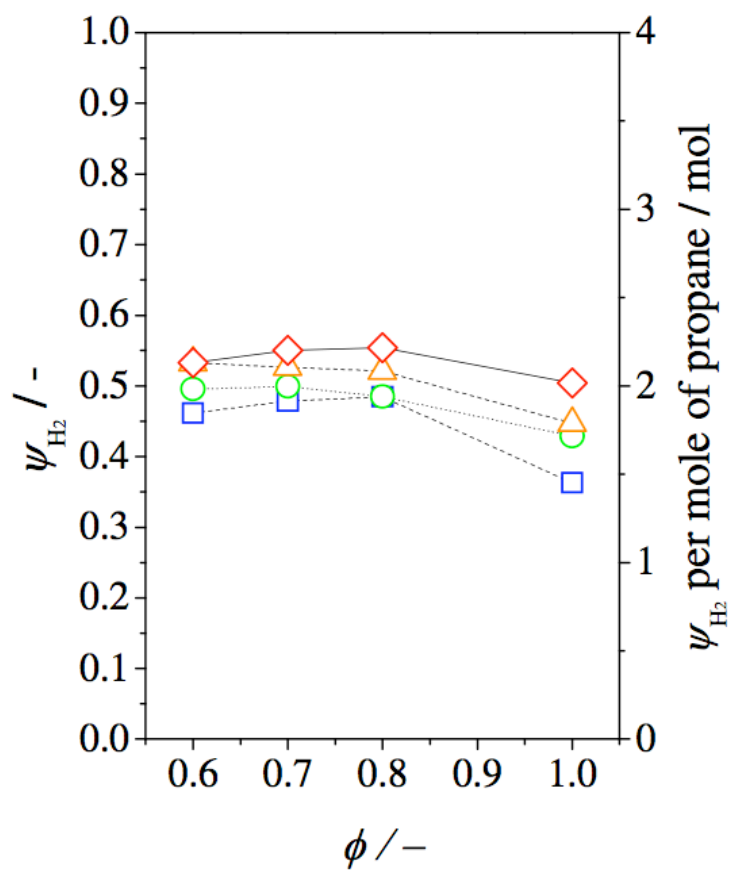

(b)

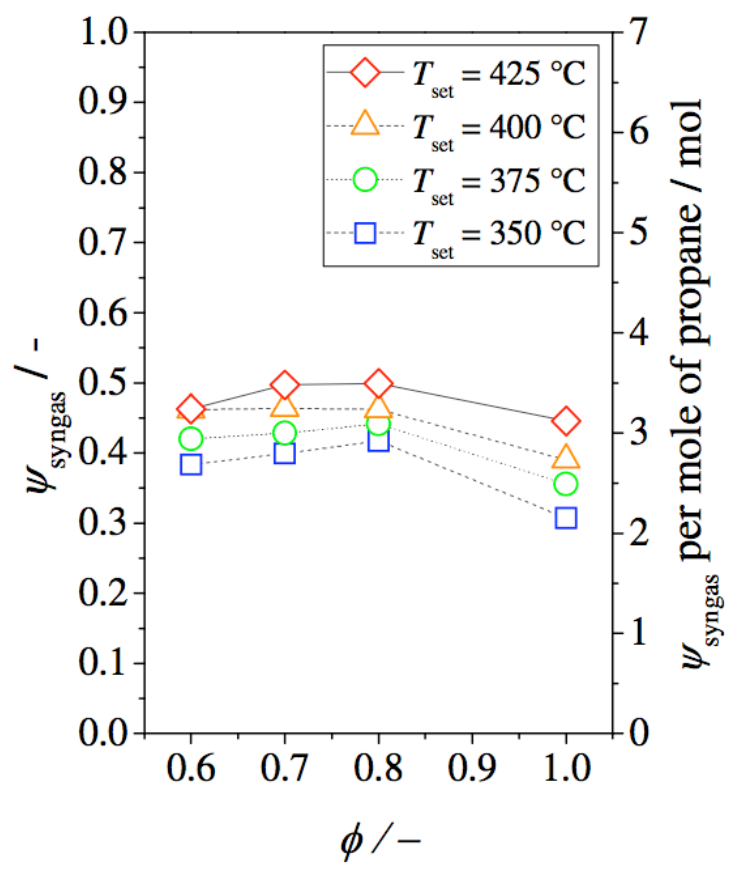

(d)

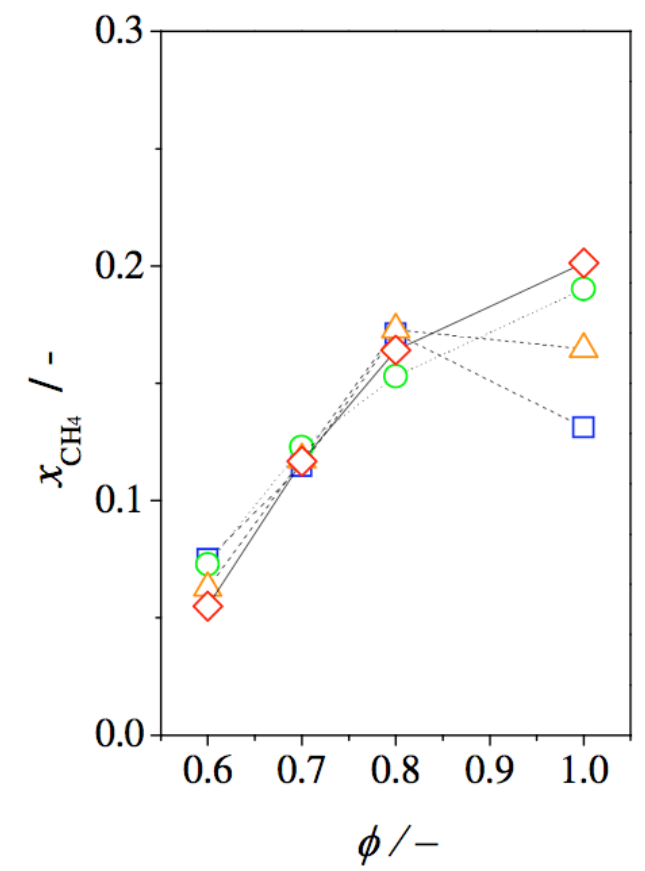

Fig. 5. Gas analysis results for propane for different fuel dilutions; (a) fuel conversion, (b) syngas yield, (c) hydrogen yield and (d) methane to inlet fuel ratio. The symbols represent different Tset: squares $\left(350{ }^{\circ} \mathrm{C}\right)$, circles $\left(375^{\circ} \mathrm{C}\right)$, triangles $\left(400^{\circ} \mathrm{C}\right)$ and diamonds $\left(425^{\circ} \mathrm{C}\right)$. 
When compared to the results obtained for n-butane, lower values were obtained with respect to syngas and hydrogen production for propane for all investigated conditions (Figs. 4b,c and $5 \mathrm{~b}, \mathrm{c})$. Due to the very similar dependence of $\psi_{\mathrm{H}_{2}}$ and $\psi_{\text {syngas }}$ of both fuels and thermodynamic behavior to $\phi$, we conclude that the effect of lower syngas generation is simply related to the lower efficiency of the catalytic nanoparticles towards propane conversion. As explained by Hohn et al. [28] and Veser et al. [30], the strength in carbon-to-hydrogen (C-H) bonds increases as the number of carbon atoms decreases, therefore making it energetically more demanding for the lower chained hydrocarbons (in this case propane) to be converted by the reaction. Lower propane conversion in comparison with n-butane are also supported by Huff et al. [31,32], who investigated various low-chained hydrocarbon fuels demonstrating the same trend of higher conversion values by increasing the number of carbon atoms in the hydrocarbon fuel. The overall lower fuel utilization values for propane had also a direct influence on $T_{\mathrm{op}}$ (Fig. 3b). In [31], also lower final CPOX reaction temperatures were obtained for the lower chained hydrocarbons.

In order to determine the best fuel dilution ratio in terms of optimal fuel conversion and syngas yield, the operating temperature at the top of the micro-reactor $\left(T_{\mathrm{op}}\right)$ should be also taken into account, since for higher $T_{\text {op }}$ or $T_{\text {set }}$, syngas production rate is enhanced (Fig. 6). For n-butane (Fig. 6a) the trend in syngas yield for $\phi=0.8$ and 0.7 are almost the same, while for propane (Fig. 6b), a fuel dilution of 0.8 shows higher syngas yield. The maximum $\psi_{\text {syngas }}$ achieved was $60 \%$ at $\phi=0.7$ for $n$-butane and $50 \%$ at $\phi=0.8$ for propane.
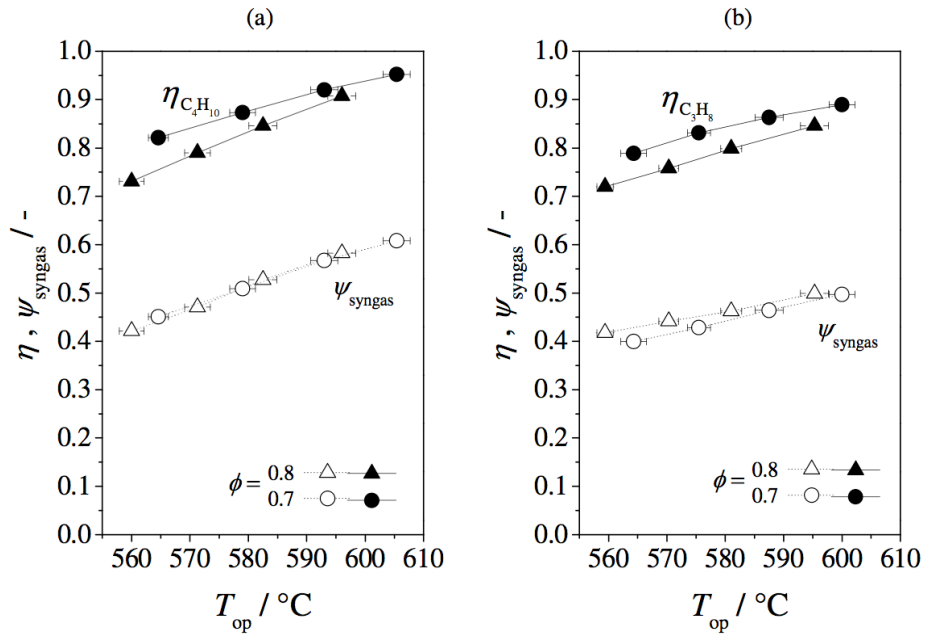

Fig. 6. Temperature effect on $\eta$ and $\psi_{\text {syngas }}$ for (a) n-butane and (b) propane. The lines for constant $\phi$ through the data points are curve fits. 
n-Butane
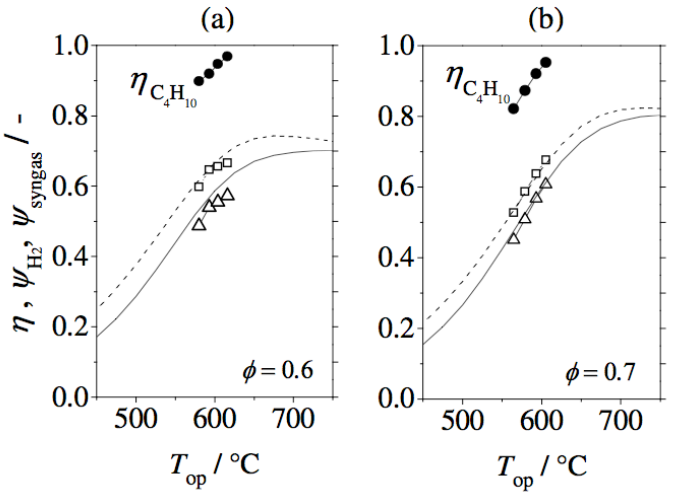

(c)

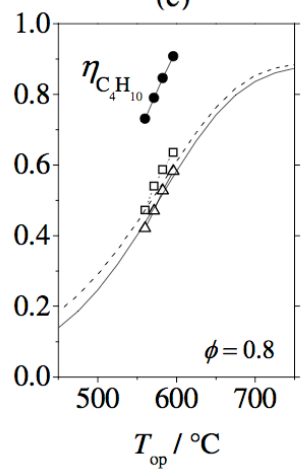

Propane

(e)

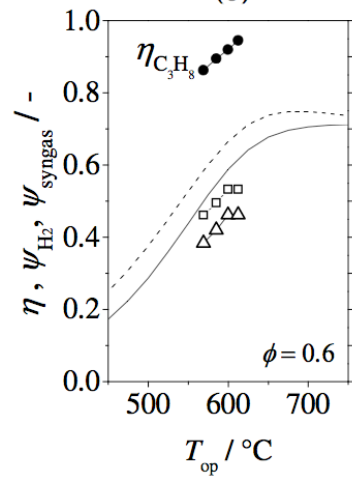

(f)

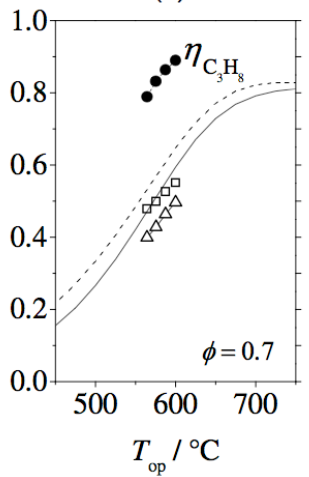

$(\mathrm{g})$

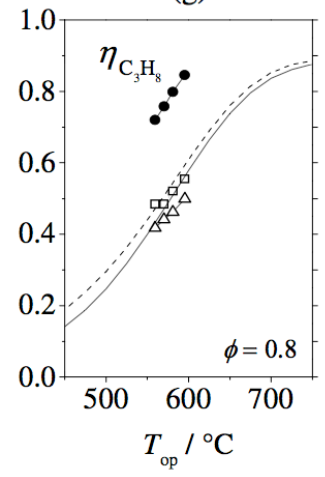

(d)

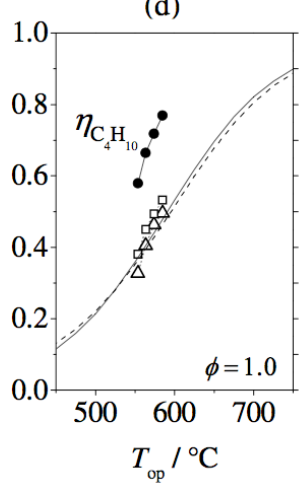

(h)

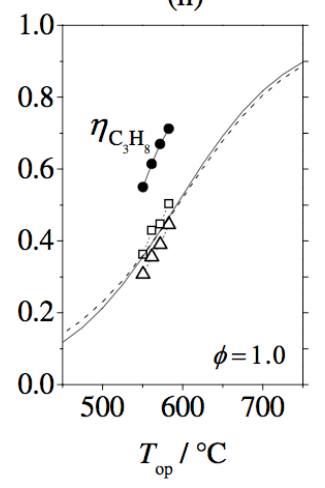

Fig. 7. Experimental results for both fuels (symbols) compared to thermodynamic equilibrium (dashed lines: $\psi_{\mathrm{H}_{2}}$; solid lines: $\left.\psi_{\text {syngas }}\right)$. For n-butane (a-d), and propane (e-h). Fuel conversion is complete at equilibrium.

As shown in Fig. 7, our experimental results indicate that for n-butane at $t_{\text {space }}$ of approximately $40-44 \mathrm{~ms}$, the obtained $\psi_{\text {syngas }}$ and $\psi_{\mathrm{H}_{2}}$ at the corresponding $T_{\mathrm{op}}$ on top of the micro-reactor are similar to those predicted by thermodynamic equilibrium calculations. For propane (Figs. 7e-h), thermodynamic values lie higher than our experimental results, with the exception at stochiometric CPOX conditions, where higher experimental syngas production is obtained. Despite similarities, thermodynamic equilibrium calculations only serve as reference for our system, since they do not take into consideration catalytic activities like fuel conversion and other complex aspects of reactant behavior along the reaction path. For example, different reaction pathways towards hydrogen generation run simultaneously in different regions inside the reactor $[33,34]$. To this end, at reactor inlet, partial oxidation competes primarily with total oxidation reaction. Due to the above described behavior of lower syngas or hydrogen generation (Fig. 7) compared to thermodynamic equilibrium towards lower $\phi$ values, we conclude that with the use of rhodium catalyst, total oxidation is enhanced due to high availability of oxygen on the catalytic surface and overcomes the thermodynamic limit for fuel-lean gas mixtures. A second catalytic effect not considered by thermodynamic equilibrium is the so called sticking effect of the reacting gases, which describes the alkane vs. oxygen competition for catalyst surface sites. As described by Veser 
et al. [30], a decrease in fuel concentration in the gas mixture (lower $\phi$ values) leads to a stronger site blocking by oxygen on the catalyst surface, hindering the fuel utilization.

Table 2 summarizes the results obtained at optimal $\mathrm{C} / \mathrm{O}$ ratios at which syngas yield is the highest for $n$-butane and propane. As tabulated here, the maximum syngas flow generated was $7.17 \mu \mathrm{mol} / \mathrm{s}$. This amount of the produced syngas corresponds to a power of $1.85 \mathrm{~W}$ which is suitable for a micro-SOFC power plant. This power is defined as the outlet mass flow of syngas specie times its lower heating value [35].

\begin{tabular}{|c|c|c|c|c|c|c|}
\hline & & \multicolumn{2}{|c|}{$\mathrm{C}_{\mathrm{x}} \mathrm{H}_{\mathrm{y}}$-species } & \multicolumn{3}{|c|}{ Syngas-species } \\
\hline \multirow{4}{*}{$\begin{array}{c}\text { n-Butane } \\
\text { at } \\
\phi=0.7\end{array}$} & & $\mathrm{C}_{4} \mathrm{H}_{10}$ & $\mathrm{CH}_{4}$ & $\mathrm{H}_{2}$ & $\mathrm{CO}$ & syngas \\
\hline & Outlet flow rate & $0.06 \pm 0.01$ & $0.24 \pm 0.01$ & $4.43 \pm 0.14$ & $2.74 \pm 0.11$ & $7.17 \pm 0.13$ \\
\hline & & $\eta$ & $x_{\mathrm{CH}_{4}}$ & $\psi_{\mathrm{H}_{2}}$ & $\psi_{\mathrm{CO}}$ & $\psi_{\text {syngas }}$ \\
\hline & Average $\pm \sigma[\%]$ & $95.2 \pm 0.1$ & $0.18 \pm 0.0$ & $66.7 \pm 0.4$ & $51.7 \pm 0.5$ & $60.0 \pm 0.5$ \\
\hline \multirow{4}{*}{$\begin{array}{c}\text { Propane } \\
\text { at } \\
\phi=0.8\end{array}$} & & $\mathrm{C}_{3} \mathrm{H}_{8}$ & $\mathrm{CH}_{4}$ & $\mathrm{H}_{2}$ & $\mathrm{CO}$ & syngas \\
\hline & $\begin{array}{l}\text { Outlet flow rate } \\
{[\mu \mathrm{mol} / \mathrm{s}]}\end{array}$ & $0.31 \pm 0.01$ & $0.32 \pm 0.01$ & $4.33 \pm 0.01$ & $2.50 \pm 0.01$ & $6.83 \pm 0.01$ \\
\hline & & $\eta$ & $x_{\mathrm{CH}_{4}}$ & $\psi_{\mathrm{H}_{2}}$ & $\psi_{\mathrm{CO}}$ & $\psi_{\text {syngas }}$ \\
\hline & Average $\pm \sigma[\%]$ & $84.3 \pm 0.4$ & $0.16 \pm 0.0$ & $55.4 \pm 0.1$ & $42.5 \pm 0.1$ & $49.8 \pm 0.1$ \\
\hline
\end{tabular}

Table 2. Summary of the gas analysis results and the outlet flow rates of the species of interest at optimal $\phi$.

Compared to previous studies on micro-structured reactors, the micro-reactor presented in this study showed very high syngas production at the intermediate temperatures investigated. The partial oxidation of propane on micro-structured reactors was studied by Aartun et al. [22,36,37], where rhodium-alumina catalysts were impregnated on Fecralloy-micro-channeled reactors. Artun et al. [37] reported propane conversion values below $40 \%$ and a hydrogen and carbon monoxide volume content in the exhaust gas of $<2 \%$ and $<3 \%$, respectively, at a reaction temperature of $600^{\circ} \mathrm{C}$. For the same fuel dilution ratio $(\phi=0.8)$, our results show double propane utilization and a hydrogen volume content of $17.2 \pm 0.1 \%$ and $\mathrm{CO}$ volume content of $9.9 \pm 0.2 \%$ in the reformed gas. For stochiometric propane CPOX conditions, Pennemann et al. [20] achieved almost complete propane conversion and hydrogen and carbon monoxide selectivities $\left(S_{\mathrm{H}_{2}}, S_{\mathrm{CO}}\right)$ of approximately $70 \%$ at $700{ }^{\circ} \mathrm{C}$ on rhodium surfaces as well. In the present study at markedly lower temperatures (below $600{ }^{\circ} \mathrm{C}$ ), despite incomplete propane utilization, $S_{\mathrm{H}_{2}}$ and $S_{\mathrm{CO}}$ values reached $88.9 \pm 0.1 \%$ and $63.8 \pm 0.5 \%$, respectively. These comparisons confirm the substantial benefits of our catalytic ceramicfoam filled micro-reactor for syngas production at intermediate temperatures. 


\subsection{Self-sufficient reaction and its effect on syngas yield}

In the previous section, the performance of the micro-reactor in terms of fuel conversion and syngas yield at different temperatures under continuous heat input was investigated. In this section, the capability of the micro-reactor to sustain a thermally self-sufficient CPOX reaction is tested for a volumetric total flow of $60 \mathrm{sccm}$ and $\phi=0.7$.

For the exothermic reaction to achieve thermal self-sustainability, we first heated the reactive gas mixture with the two built-in heaters fabricated at the bottom of the carrier (Heater $\mathrm{A}$ is located underneath the micro-reactor and heater $\mathrm{B}$ is placed prior to reactor inlet, Fig. 1c). The function of Heater B is mainly to heat up the incoming gas mixture. We used a total power input of $9.4 \mathrm{~W}$ and a power distribution of heaters A and B of nearly $1: 1$. Once the reaction was initiated, which occurred at a reactor temperature between 460 and $475{ }^{\circ} \mathrm{C}$, the heaters were turned off (at $485^{\circ} \mathrm{C}$ ). The time lapse between the temperature raise at the entrance of the reactor and the temperature readings at the thermocouples on top of the micro-reactor during the rapid heating phase was the reason for the higher ignition temperature range obtained between these start-up experiments and those in the previous Section 3.1 (Fig. 2). The start-up heating method and the resulting temperature are depicted in Fig. 8, where $T_{\text {carrier }}$ represents the temperature at the top of heater B.

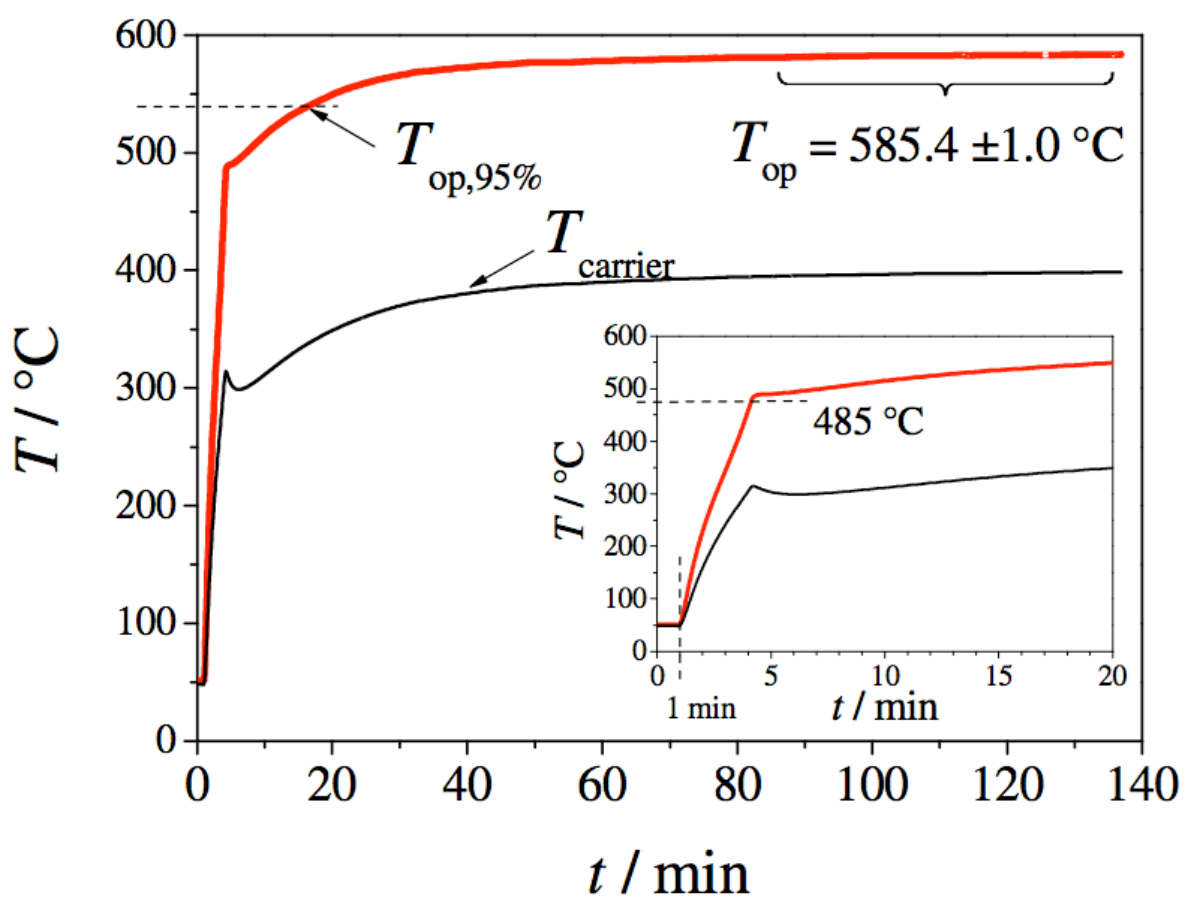

Fig. 8. Temperature vs. time behavior during reaction activation (from $t=1 \mathrm{~min}$ until $T=485^{\circ} \mathrm{C}$ ) and thermally self-sustained conditions. $T_{\text {carrier }}$ represents the temperature at the top of heater $B$. 
For calculation of the power consumption during start-up, the lower heating value of butane, the n-butane inlet flow, the power supplied to reach $485{ }^{\circ} \mathrm{C}$ and the time spent to achieve $95 \%$ of $T_{\text {op }}$ were taken into consideration. For our experiment, a total power of $8.5 \mathrm{~W}$ was consumed in order to achieve $95 \%$ of steady state temperature in Kelvin $\left(T_{\mathrm{op}}=585.4 \pm 1.0^{\circ} \mathrm{C}, T_{\mathrm{op}, 95 \%}=542.5^{\circ} \mathrm{C}\right)$. When compared to [23], where heating times were in the order of $400 \mathrm{~s}$, the heating element in our setup could be substantially improved. For instance, a screen-printed heater on the silicon wafer itself would have the potential of being not only faster but also more energy efficient. That in turn makes the fabrication process more difficult.

The gas analysis results for both self-sustained reaction experiments are tabulated in Table 3. The exhaust gas was analyzed after $60,85,110$ and 135 min of reaction. The temperatures of the micro-reactor at which these samples were taken were in the range $581.1^{\circ} \mathrm{C}$ and $586.4^{\circ} \mathrm{C}$.

\begin{tabular}{l|cc|ccc}
\hline & \multicolumn{2}{c}{$\mathrm{C}_{\mathrm{x}} \mathrm{H}_{\mathrm{y}}$-species } & \multicolumn{3}{c}{ Syngas-species } \\
\hline & $\mathrm{C}_{4} \mathrm{H}_{10}$ & $\mathrm{CH}_{4}$ & $\mathrm{H}_{2}$ & $\mathrm{CO}$ & syngas \\
Outlet flow rate $[\mu \mathrm{mol} / \mathrm{s}]$ & $1.03 \pm 0.01$ & $0.18 \pm 0.01$ & $6.09 \pm 0.03$ & $3.25 \pm 0.03$ & $9.34 \pm 0.03$ \\
& & & & & \\
& $\boldsymbol{\eta}$ & $x_{\mathrm{CH}_{4}}$ & $\psi_{\mathrm{H}_{2}}$ & $\psi_{\mathrm{CO}}$ & $\psi_{\text {syngas }}$ \\
& $60.9 \pm 0.6$ & $0.07 \pm 0.0$ & $46.1 \pm 0.6$ & $30.7 \pm 0.4$ & $39.1 \pm 0.5$ \\
\hline \hline
\end{tabular}

Table 3. Average gas analysis results from runs 1 and 2 after 60, 85, 110 and 135 min of reaction.

When comparing the results tabulated in Table 3 with those obtained during constant heating (Section 3.1), the fuel utilization is reduced from over $90 \%$ to nearly $60 \%$. Also, $\psi_{\mathrm{H}_{2}}, \psi_{\mathrm{CO}}$ and consequently $\psi_{\text {syngas }}$ drop by approximately $20 \%$. One reason for the reduced $\psi_{\text {syngas }}$ is the insufficient heat at the micro-reactor where hydrogen generation pathways like steam reforming take place. The strong endothermic steam reforming reaction is known to contribute to higher hydrogen and carbon monoxide production [27,34]. Also, compared to the experiments in Section 3.1, no preheating of the inlet gases was possible, which is known to reduce fuel utilization and $\mathrm{CO}$ production rate [38]. The second factor affecting the results is $t_{\text {space, }}$ which was approximately $21 \mathrm{~ms}$, compared to $40-44 \mathrm{~ms}$ in the experiments in Section 3.1. As explained in [24], low space times result in lower fuel utilization, as the reactants have less time to be converted.

Due to the very small size of the system, heat losses have been shown to play an important role in the fuel utilization and in the partial oxidation of small-size reactors [38]. We estimate here the heat loss of reaction $\left(\dot{Q}_{\text {loss, reaction }}\right)$ at steady state in both testing modes (at $\phi=0.7$ ) from

$$
\dot{Q}_{\text {loss, reaction }}=\sum \dot{n}_{\text {outlet }} \cdot h_{\text {outlet }}\left(T_{\text {op }}\right)-\sum \dot{n}_{\text {inlet }} \cdot h_{\text {inlet }}\left(T_{\text {op }}\right)
$$


where $\dot{n}_{\text {inlet }}$ and $\dot{n}_{\text {outlet }}$ are the inlet and outlet mole flow rates and $h_{\text {inlet }}\left(T_{\text {op }}\right)$ and $h_{\text {outlet }}\left(T_{\text {op }}\right)$ denote the inlet and outlet molar enthalpies at an assumed constant temperature $T_{\mathrm{op}}$. For the continuous heating mode, two different $T_{\text {op }}$ values are close to that obtained by the selfsustained mode. The calculated values of are shown in Table 4. In the cases studied here, approximately 4 times more heat is lost in the self-sustained mode. As a consequence, a lower fuel utilization and a lower syngas production is obtained. However, in order to determine the optimal operation mode for a steady state reaction, the power supplied from the screen-printed heaters has to be taken into account. For the continuous heating mode at steady state at $T_{\text {op }}=579^{\circ} \mathrm{C}$ and $T_{\text {op }}=593^{\circ} \mathrm{C}$, a heating power of $1.9 \mathrm{~W}$ and $2.1 \mathrm{~W}$ (for $T_{\text {set }}=375^{\circ} \mathrm{C}$ and $\left.T_{\text {set }}=400^{\circ} \mathrm{C}\right)$, respectively, was necessary. Employing Eq. (7),

$$
\dot{Q}_{\text {loss }, \text { total }}=\dot{Q}_{\text {loss, reaction }}+P_{\text {heater }}
$$

where $P_{\text {heater }}$ is the heating power provided by the built-in heaters, total heat losses $\dot{Q}_{\text {loss,total }}$ of $2.88 \mathrm{~J} \cdot \mathrm{s}^{-1}$ and $3.06 \mathrm{~J} \cdot \mathrm{s}^{-1}$ are obtained for the continuous heating mode at $579^{\circ} \mathrm{C}$ and $593^{\circ} \mathrm{C}$, respectively. For the self-sustained mode, $\dot{Q}_{\text {loss,total }}$ equals $1.90 \mathrm{~J} \cdot \mathrm{s}^{-1}$, which implies a better performance in terms of total heat losses for the reactor system.

An important aspect of such system is the controlled production of methane. For the selfsustained reaction, production of methane per inlet molar fuel flow was more than halved compared to our results obtained in Section 3.1 (Table 3). Obviously, the lower n-butane conversion contributed to this drop. Control over methane production could be possible by enhancing e.g. steam reforming reaction, as discussed previously. In a system where fuel may not be entirely utilized from SOFC membranes for power generation, unconverted gases like methane would need to be consumed completely in a post-combustor in order to avoid exhausting flammable gases to the environment [29]. Combustion of methane may be energy demanding as its concentration in the exhaust gas increases, especially at our intermediate temperature range of interest [39]. According to our results, realizing the CPOX reaction at low $\phi$ values would be necessary in order to avoid high concentration of methane in the exhaust gas, enhancing at the same time the fuel conversion.

After 280 hours of operation combined, no cracks or other kind of deformations were noticed on neither the micro-reactor bed nor the micro-reactor structure itself, underpinning the very good mechanical stability and reliability of the reactor. 


\begin{tabular}{l|ccc|cc}
\hline & $\begin{array}{c}T_{\mathrm{op}} \\
/{ }^{\circ} \mathrm{C}\end{array}$ & $\begin{array}{c}\dot{Q}_{\text {loss,reaction }} \\
/ \mathrm{J} \mathrm{mol}^{-1} \mathrm{C} 4 \mathrm{H} 10\end{array}$ & $\begin{array}{c}\dot{Q}_{\text {loss,reaction }} \\
/ \mathrm{J} \mathrm{mol}^{-1} \text { feed gas }\end{array}$ & $\begin{array}{c}P_{\text {heater }} \\
/ \mathrm{J} \mathrm{s}^{-1}\end{array}$ & $\begin{array}{c}\dot{Q}_{\text {loss,total }} \\
/ \mathrm{J} \mathrm{s}^{-1}\end{array}$ \\
\hline $\begin{array}{l}\text { Continuous } \\
\text { heating mode }\end{array}$ & 579 & -1.298 & -609.8 & 1.9 & -2.877 \\
\hline $\begin{array}{l}\text { Self-sustained } \\
\text { mode }\end{array}$ & 593 & -1.272 & -597.4 & 2.1 & -3.057 \\
\hline \hline
\end{tabular}

Table 4. Calculated heat loss for the two testing modes used in this study at $\mathbf{C} / \mathbf{O}=\mathbf{0 . 7} . \dot{Q}_{\text {loss,reaction }}$ is given in $\mathbf{J}$ per mole of inlet butane and $\mathbf{J}$ per gram of the feed gas, while $\dot{Q}_{\text {loss,total }}$ is given in total values.

\section{Conclusion}

In this study, the capability of a novel micro-fabricated reactor concept to deliver high syngas yield was investigated by means of partial oxidation of n-butane and propane. The CPOX reaction was accomplished by the use of a rhodium doped catalyst embedded inside a foamlike ceramic bed inside the micro-reactor.

Under continuous heating conditions and at $t_{\text {space }}=40-44 \mathrm{~ms}$, the micro-reactor was able to deliver syngas yield as high as $60 \%$ for n-butane and $50 \%$ for propane for an optimal $\mathrm{C} / \mathrm{O}$ ratio of 0.7 and 0.8 , respectively. Enough syngas $(7.2$ and $6.8 \mu \mathrm{mol} / \mathrm{s}$ equivalent to $1.85 \mathrm{~W}$ and $1.76 \mathrm{~W}$ for $\mathrm{n}$-butane and propane, respectively) was produced to power a micro-SOFC device. These experimental results were shown to be close to thermodynamic equilibrium behavior, especially for the gas mixtures close to stochiometric partial oxidation conditions.

It was also shown that the micro-reactor is able to reach steady state temperature and syngas production in a thermally self-sustained mode. In this case, however, syngas yield dropped to $39 \%$ for n-butane, due to insufficient heat through the entire reactor, the higher heat loss by the reactants and the lower residence time. Despite its higher reaction heat loss, the selfsufficient reaction is proven to be the most efficient heating mode when the total heat loss of the reactor system is taken into account.

The presented micro-reactor bed demonstrated a good thermal and catalytic stability through all experiments. Overall, the catalytic results of this study prove the suitability of this novel micro-reactor for delivering high conversion of fuel and high syngas yields. In addition to its generic value, the present micro-reactor was fabricated and investigated with the additional aim of being integrated with a micro-SOFC membrane and a post-combustor to piece together a first of its kind portable micro-SOFC power plant. 


\section{Acknowledgements}

We gratefully acknowledge the financial support of the Swiss National Science Foundation (SNSF) within the framework of the SINERGIA project "ONEBAT" (CRSI11_126830). We thank Peter Heeb at the Interstaatliche Hochschule für Technik Buchs (NTB) for the fabrication of the micro-reactor.

\section{References}

1. A. Evans, A. Bieberle-Hutter, J. L. M. Rupp, and L. J. Gauckler, Review on microfabricated micro-solid oxide fuel cell membranes. Journal of Power Sources, 2009. 194(1): p. 119-129.

2. J.C. Ruiz-Morales, D. Marrero-Lopez, M. Galvez-Sanchez, J. Canales-Vazquez, C. Savaniu, and S. N. Savvin, Engineering of materials for solid oxide fuel cells and other energy and environmental applications. Energy \& Environmental Science, 2010. 3(11): p. 1670-1681.

3. K.B. Min, S. Tanaka, and M. Esashi, MEMS-based polymer electrolyte fuel cell. Electrochemistry, 2002. 70(12): p. 924-927.

4. T. Yoshitake, H. Kimura, S. Kuroshima, S. Watanabe, Y. Shimakawa, T. Manako, S. Nakamura, and Y. Kubo, Small direct methanol fuel cell pack for portable applications. Electrochemistry, 2002. 70(12): p. 966-968.

5. M. Horiuchi, F. Katagiri, J. Yoshiike, S. Suganuma, Y. Tokutake, H. Kronemayer, and W. G. Bessler, Performance of a solid oxide fuel cell couple operated via in situ catalytic partial oxidation of n-butane. Journal of Power Sources, 2009. 189(2): p. 950-957.

6. S. Assabunrungrat, V. Pavarajarn, S. Charojrochkul and N. Laosiripojana, Thermodynamic analysis for a solid oxide fuel cell with direct internal reforming fueled by ethanol. Chemical Engineering Science, 59 (2004), pp. 6015-6020.

7. T. Suzuki, T. Yamaguchi, K. Hamamoto, Y. Fujishiro, M. Awano, and N. Sammes, A functional layer for direct use of hydrocarbon fuel in low temperature solid-oxide fuel cells. Energy \& Environmental Science, 2011. 4(3): p. 940-943.

8. V.M. Janardhanan, S. Appari, S. Jayanti, O. Deutschmann, Numerical study of onboard fuel reforming in a catalytic plate reactor for solid-oxide fuel cells. Chemical Engineering Science, 66 (2011), pp. 490-498

9. $\quad$ E.P. Murray, T. Tsai, and S. A. Barnett, A direct-methane fuel cell with a ceria-based anode. Nature, 1999. 400(6745): p. 649-651.

10. Z. Shao, S. M. Haile, J. Ahn, P. D. Ronney, Z. Zhan, and S. A. Barnett, A thermally self-sustained micro solid-oxide fuel-cell stack with high power density. Nature, 2005. 435(7043): p. 795-8.

11. G.S. Jackson and S. A. Seyed-Reihani, Catalytic partial oxidation of n-butane over Rh catalysts for solid oxide fuel cell applications. Catalysis Today, 2010. 155(1-2): p. 7583. 
12. G. Kolb, V. Hessel, V. Cominos, H. Pennemann, J. Schurer, R. Zapf, and H. Lowe, Microstructured fuel processors for fuel-cell applications. Journal of Materials Engineering and Performance, 2006. 15(4): p. 389-393.

13. D.E. Park, T. Kim, S. Kwon, C. K. Kim, and E. Yoon, Micromachined methanol steam reforming system as a hydrogen supplier for portable proton exchange membrane fuel cells. Sensors and Actuators a-Physical, 2007. 135(1): p. 58-66.

14. J.D. Morse, R. S. Upadhye, R. T. Graff, C. Spadaccini, H. G. Park, and E. K. Hart, A MEMS-based reformed methanol fuel cell for portable power. Journal of Micromechanics and Microengineering, 2007. 17(9): p. S237-S242.

15. A.B. Pattekar and M. V. Kothare, A radial microfluidic fuel processor. Journal of Power Sources, 2005. 147: p. 116-127.

16. Y. Kawamura, N. Ogura, T. Yamamoto, A. Igarashi, A miniaturized methanol reformer with Si-based microreactor for a small PEMFC. Chemical Engineering Science, 61 (2006), pp. 1092-1101

17. J.Y. Jang, Y.X. Huang, C.H. Cheng, The effects of geometric and operating conditions on the hydrogen production performance of amicro-methanol steam reformer. Chemical Engineering Science, 65 (2010), pp. 5495-5506.

18. S. Tanaka, K.-S. Chang, K.-B. Min, D. Satoh, K. Yoshida, and M. Esashi, MEMSbased components of a miniature fuel cell/fuel reformer system. Chemical Engineering Journal, 2004. 101: p. 143-149.

19. O. Younes-Metzler, J. Svagin, S. Jensen, C. H. Christensen, O. Hansen, and U. Quaade, Microfabricated high-temperature reactor for catalytic partial oxidation of methane. Applied Catalysis a-General, 2005. 284(1-2): p. 5-10.

20. H. Pennemann, V. Hessel, G. Kolb, H. Lowe, and R. Zapf, Partial oxidation of propane using micro structured reactors. Chemical Engineering Journal, 2008. 135: p. S66-S73.

21. A.L.Y. Tonkovich, J. L. Zilka, M. R. Powell, and C. J. Call, The catalytic partial oxidation of methane in a micro-channel chemical reactor. Proc. of 2nd International Conference on Microreaction Technology., 1998: p. 45-53.

22. T. Gjervan, H. J. Venvik, I. Aartun, A. Holmen, O. Gorke, P. Pfeifer, and K. Schubert, Hydrogen production from propane through partial oxidation and autothermal reforming in microstructured reactors. Abstracts of Papers of the American Chemical Society, 2003. 225: p. U866-U866.

23. A.J. Santis-Alvarez, M. Nabavi, N. Hild, D. Poulikakos, and W. J. Stark, A fast hybrid start-up process for thermally self-sustained catalytic n-butane reforming in microSOFC power plants. Energy \& Environmental Science, 2011. 4(8): p. 3041-3050.

24. N. Hotz, M. Stutz, S. Loher, W. J. Stark, and D. Poulikakos, Syngas production from butane using a flame-made $\mathrm{Rh} / \mathrm{Ce}_{0.5} \mathrm{Zr}_{0.5} \mathrm{O}_{2}$ catalyst. Applied Catalysis B: Environmental, 2007. 73: p. 336-344.

25. R.P. O'Connor, E. J. Klein, and L. D. Schmidt, High yields of synthesis gas by millisecond partial oxidation of higher hydrocarbons. Catalysis Letters, 2000. 70: p. 99-107.

26. N. Hotz, N. Koc, T. Schwamb, N. C. Schirmer, and D. Poulikakos, Catalytic Porous Ceramic Prepared In-Situ by Sol-Gelation for Butane-to-Syngas Processing in Microreactors. AIChE Journal, 2009. 55(7): p. 1849-1859. 
27. N. Hotz, N. Osterwalder, W. J. Stark, N. R. Bieri, and D. Poulikakos, Disk-shaped packed bed micro-reactor for butane-to-syngas processing. Chemical Engineering Science, 2008. 63(21): p. 5193-5201.

28. K.L. Hohn, C. C. Huang, and C. Cao, Catalytic ignition of light hydrocarbons. Journal of Natural Gas Chemistry, 2009. 18(2): p. 115-123.

29. A. Bieberle-Hütter, D. Beckel, A. Infortuna, U. P. Muecke, J. L. M. Rupp, L. J. Gauckler, S. Rey-Mermet, P. Muralt, N. R. Bieri, N. Hotz, M. J. Stutz, D. Poulikakos, P. Heeb, P. Müller, A. Bernard, R. Gmür, and T. Hocker, A micro-solid oxide fuel cell system as battery replacement. Journal of Power Sources, 2008. 177: p. 123-130.

30. G. Veser, M. Ziauddin, and L. D. Schmidt, Ignition in alkane oxidation on noblemetal catalysts. Catalysis Today, 1999. 47(1-4): p. 219-228.

31. M. Huff and L. D. Schmidt, Production of Olefins by Oxidative Dehydrogenation of Propane and Butane over Monoliths at Short-Contact Times. Journal of Catalysis, 1994. 149(1): p. 127-141.

32. M. Huff, P. M. Torniainen, and L. D. Schmidt, Partial Oxidation of Alkanes over Noble-Metal Coated Monoliths. Catalysis Today, 1994. 21(1): p. 113-128.

33. M.J. Stutz and D. Poulikakos, Effects of microreactor wall heat conduction on the reforming process of methane. Chemical Engineering Science, 2005. 60(24): p. 69836997.

34. R. Horn, K. A. Williams, N. J. Degenstein, A. Bitsch-Larsen, D. D. Nogare, S. A. Tupy, and L. D. Schmidt, Methane catalytic partial oxidation on autothermal Rh and Pt foam catalysts: Oxidation and reforming zones, transport effects, and approach to thermodynamic equilibrium. Journal of Catalysis, 2007. 249(2): p. 380-393.

35. M.J. Moran and H.N. Shapiro, Fundamentals of Engineering Thermodynamics. 4th Edition, 2004, Chichester, England.

36. I. Aartun, H. J. Venvik, A. Holmen, P. Pfeifer, O. Gorke, and K. Schubert, Temperature profiles and residence time effects during catalytic partial oxidation and oxidative steam reforming of propane in metallic microchannel reactors. Catalysis Today, 2005. 110(1-2): p. 98-107.

37. I. Aartun, T. Gjervan, H. Venvik, O. Gorke, P. Pfeifer, M. Fathi, A. Holmen, and K. Schubert, Catalytic conversion of propane to hydrogen in microstructured reactors. Chemical Engineering Journal, 2004. 101(1-3): p. 93-99.

38. S.A. Seyed-Reihani and G. S. Jackson, Influence of thermal conditions on partial oxidation of $n$-butane over supported Rh catalysts. Applied Catalysis a-General, 2009. 353(2): p. 181-192.

39. P. Gelin and M. Primet, Complete oxidation of methane at low temperature over noble metal based catalysts: a review. Applied Catalysis B-Environmental, 2002. 39(1): p. $1-37$. 